\title{
COMPLEXITY DEVELOPMENT AND SIMPLIFICATION IN SYSTEMIC TYPOLOGY: TYPES OF CHANGES IN THE INTERNAL DETERMINANT
}

Keywords: internal determinant, synthetic complexification, synthetic simplification, analytic simplification, analytic complexification

\begin{abstract}
The article deals with a developmental cline of the ego-et-nunc communicative scope in Slavic versus Germanic and Romance. The author posits a two pathway grammaticalization for the Indo-European ego-et-nunc communicative scope progressing along the axis of syntheticity and the axis of analyticity respectively. The prospective perspective (aspect) is typical of Slavic while the retrospective perspective is observed in the analytic Western European languages. Each of the two grammaticalization pathways is characterized by four possible changes as determined by particular configurations of the societal factors (synthetic complexification, synthetic simplification, analytic simplification, analytic complexification). The author places the systematic typology of Mel'nikov in a wider context of areal-typological and genealogical research.
\end{abstract}

\section{Introduction}

In the first article (Danylenko 2018) dealing with the postulates of the systemic typology of Mel'nikov (1971, 1973, 1986, 2003) I discussed the correlation of linguistic patterning and societal structures. In particular, I outlined a system of societal factors and their variables which, according to both Mel'nikov and and Trudgill, correlate with different patterning in the inflecting languages in comparison with other language systems. The principle difference, however, between the two theories lies in the introduction by Mel'nikov of the internal determinant or, the "communicative 
scope", which mediates between the external determinant and linguistic patterning (see Sections 2-2.2).

Explicating the postulates of Mel'nikov's theory and their validity for modern linguistics allows me to make more precise my grounds for the claim that both complexity development and simplification process should be conceived of primarily with the help of the genealogical and typological parameters; I believe that simplification in some cases may largely be dependent on the typological and areal parameters (see Sections 3, 3.2, 3.3). Despite its conceptual simplicity and allegedly empirical transparency, contact is $\mathrm{not}$, as has been stated, the major factor in simplification processes. One should bear in mind that whether a certain change instantiates complexification or simplification depends primarily on the type of a particular internal determinant which, though looking elusive from the positivistic vantage point, should not be treated teleologically (Schwegler 1990: 177). Hence, for instance, the distinction between synthetic complexification and synthetic si mplification (Sections 3.1 and 3.3), on the one hand, and analytic simplification and analytic complexification (Sections 3.2 and 3.4), on the other hand.

In Section 4, I provide a synopsis of four possible types of changes in the internal determinant typical of an inflecting system together with the respective configurations of the external determinants (societal factors and their variables) as elaborated in the systemic theory of Mel'nikov and the sociolinguistic typology of Trudgill (2011, also 1996, 1997, 2010).

\section{The two perspectives of the ego-et-nunc communicative scope}

The development of the initial Indo-European ego-et-nunc communicative scope might have progressed along two parallel pathways of grammaticalization. One pathway is discerned in Slavic which is characterized by the prospective perspective of the ego-et-nunc communicative scope (Section 2.1). The second pathway is reconstructed for the typologically innovative Indo-European languages, primarily Germanic and Romance, which have acquired the opposite, retrospective perspective (Section 2.2).

\subsection{The prospection of the ego-et-nunc communicative scope in Slavic}

As the "conservative" variety of Indo-European (Danylenko 2013: 153-156), the internal determinant of Slavic is derivative from the initial, Indo-European ego-et-nunc communicative scope (Danylenko 2003: 347-366); the latter can be conceived of in terms of a psychological rather than chronological notion of "current relevance" (here-and-now) (Fleischman 1983: 192, 204). ${ }^{1}$

The here-and-now is initially encoded, to use Fleischman's (1983) terminology, as an "aspect of retrospection" for the present perfect tense with the "resultative meaning" tending to get regrammatized as preterite (see Drinka 2017: 58-72), and an "aspect of prospection" for the 
As Mel'nikov (1980, 2003: 118-120) postulated, a prototypical clause in Slavic rests on the event-oriented communication with the economical use (fusion) of both relational and derivational meanings. In other words, the Slavic prototypical clause marks an event evolving from the moment of speaking and involving other participants by encoding them through morphological case marking. The speaker may be seen in terms of an agent initiating and controlling a series of interconnected actions (see Dixon 1979: 98). The orientation of the ego-et-nunc communicative scope in this case is viewed as the pros pective perspective (prospection a s p e c t) of an event getting split into a series of connected actions; initiated at the moment of speaking, such an event is unfolding toward posterioritas, see Figure 1.

In compliance with the concept domination of prospection (Danylenko 2012: 7, fn. 2), ${ }^{2}$ East Slavic appears as the most conservative Indo-European language. Hence, as Mel'nikov (2003: 118, 119) surmised, the lack of perfect tenses and an "underdeveloped" inflecting nature of the new preterite like R ja sdelal (pst. m. sg.) 'I did' in comparison with the perfective future R ja sdelaju (1sg.) which, marked by the person desinence, "conveniently" denotes a future event initiated by the speaker at the moment of utterance. Such an event may consist of several micro-events (connected actions) encompassing other "acting participants" marked with the help of morphological cases. This might explain the case-stable nature of Russian (and Lithuanian) that historically has tended to accrue new morphological cases (see Mel'nikov 1988: 24). ${ }^{3}$

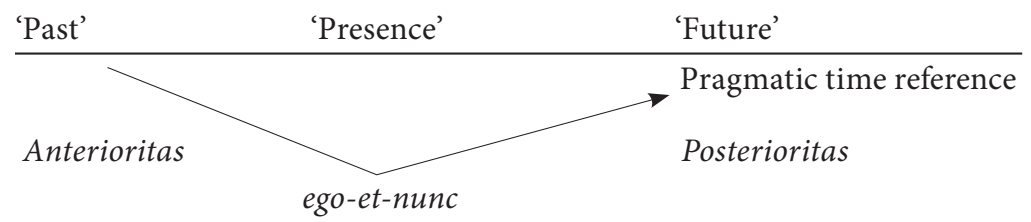

Figure 1. The prospection of the ego-et-nunc communicative scope in Slavic

It is not accidental, according to Mel'nikov (2003: 119; also Potebnja 1941: 205-206), that in East Slavic the passive construction is realized in the past tense only, see (1); in the present tense it is substituted for by a pseudo-active (middle voice) construction

complex (compound) future tense with the auxiliary from the inceptive (phasal) perfective 'to take' in Romance, Germanic, and Slavic (see Danylenko 2011, 2012: 6-8).

2 Our understanding of "prospection" (a future situation viewed as evolving from the moment of speaking by the agent) and "retrospection" (a past situation viewed in terms of its present repercussions) (Fleischman 1983: 191, 192) derives from the distinction of two opposite concept dominations in verbal encoding as represented by the synthetic (East) Slavic and the analytic Western European languages respectively (cf. Capell 1965; Danylenko 200o/1997: 41-47, 64-65, 2003: 361-366)

3 Suffice it to name here, following Mel'nikov (1980), the modern Russian "second" ("truly") locative and "second" (partitive) genitive like R v les-u 'in a forest', saxar-u '(some) sugar' next to the first ("truly oblique") locative o les- $e$ 'about a forest' and the first genitive saxar-a 'sugar' (Sakhno 2011). Here also belong three new "truly" locative - illative, allative, adessive cases partly preserved in modern Lithuanian and some southern and eastern archaic dialects (Kulikov 2009: 443-444, 448-450). 
with a reflexive verb, see (2). ${ }^{4}$ However, Slavic languages with a less advanced prospection of the event-oriented ego-et-nunc scope do know passive (periphrastic) constructions in the present, see (3).

(1) $\mathrm{R}$ dom byl postrojen rabotnikami house-nom.sg.m. be-aux.pst.sg.m. build-ppp.sg.m. worker-instr.pl.m. 'The house was built by workers.'

(2) R dom stroitsja rabotnikami house-nom.sg.m. build-prs.3sg.refl. workers-instr.pl.m. 'The house is being built by workers.'

(3) P budynek jest budowany przez robotników house-nom.sg.m. be-aux.prs.3sg. build-ppp.sg.m. through workers-acc.pl.m. 'The house is being built by workers.'

\subsection{The retrospection of the ego-et-nunc communicative scope in Romance and Germanic}

Although genetically and typologically related to the synthetic (conservative) Slavic languages, the analytic (innovative) Western European (primarily, Romance and Germanic) languages have historically acquired the retros pective perspective ( $r$ e t r o s p e ct i o $n$ a s p e c $t$ ) of the Indo-European ego-et-nunc communicative scope. The utterance in these languages is oriented towards anterioritas viewed as a result of an event that has preceded the moment of speaking (see Dixon 1979: 98). The appearance of a well-developed system of perfect tenses accompanied by a historical loss of aspects in Romance and Germanic is one of the corollaries to the changes in the concept domination of the initial (Indo-European) ego-et-nunc scope. Under retrospection, the speaker is "not able" to either initiate or control the future event, whence an array of modals for future reference in English; the participants of a situation tend to be presented in a rather "awkward" (rigid) order with a simplified overt morphological case marking.

Extralinguistic time

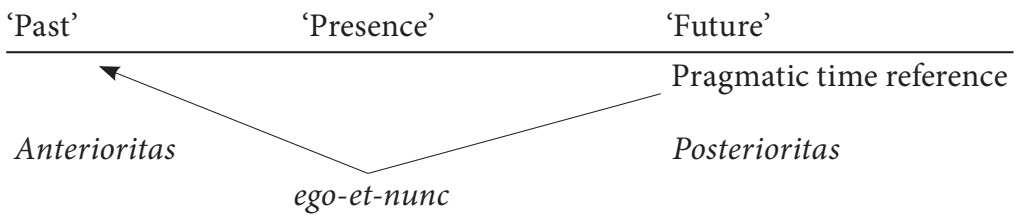

Figure 2. The retrospection of the ego-et-nunc communicative scope in Romance and Germanic

4 In this case, Mel'nikov unwittingly reiterates the interpretation of passive and pseudo-active constructions in Slavic suggested by Popov (1881: 298-299), a Ukrainian linguist who explored the development of object and transitivity in the history of Russian and other Indo-European languages (see Danylenko 2016). 
Following Mel'nikov (2003: 108-113), one can conclude that changes in the internal determinant of Romance and Germanic, i.e. the strengthening of their s e c o n d a r y a $\mathrm{n}$ a l y $\mathrm{t}$ i c features (Baudouin de Courtenay), including the elaboration on perfect tense paradigms and a loss of aspects, was triggered by the corresponding changes in their external determinant, language contact being part thereof. High amounts of adult language contact provoke an increase of the heterogeneity of speech communities as well as a gradual decrease in the degree of heredity in the transmission of linguistic and cultural experience (see Trudgill 2011: 6). Such changes may have brought about the continual waning of genetic diversity in the languages of Western Europe, where Romance and Germanic are predominant (Standard Average European) languages in use today. Note that typological similarities (analyticity) in genetically related languages may lead, under converging external determinants, to the areal convergence of linguistic structures. One of the starkest examples is the formation of Continental Scandinavian which spread over the earliest division of Scandinavian between West (Norwegian, Faroese, Icelandic) and East (Swedish, Danish) (Orr 1999: 148-149).

Conversely, the strengthening of primary sy n the t ic features in Slavic, and especially East Slavic, was provoked by a lack of major changes in the external (social) determinant for more than 1,5 thousand years (Shevelov 1965: 607). This is why, the historical enlargement of comparatively isolated sedentary speech communities and the ensuing increase of constraints on the communication intervals lead to the strengthening of the event-oriented prospection of the ego-et-nunc communicative scope. The results of this historical adaptation are viewed as "mature" linguistic phenomena (Dahl 2004: 2) that presuppose a lengthy period of historical development. Reiterating unbekannterweise Mel'nikov's (1988: 24-25) stance, Dahl (2004: 111) admitted that "reviewing the candidates for inclusion in the class of mature linguistic phenomena, we find that the most obvious one is inflecting morphology". Quite in the same vein, Trudgill (2011: 150) argued unequivocally that inflecting (Indo-European) languages with high fusion are the supreme example of the outcome of linguistic complexification, as well as the supreme demonstration of the nature of mature phenomena. ${ }^{5}$

\footnotetext{
The use of the term "mature" in regard to the inflecting languages by Dahl is, however, aprioristically undistinguishable from August Schleicher's (1873/1863) language-as-organism evolutionary hypothesis. In accordance with the Schleicherian organic school, linguistic evolution, on a par with biological evolution, was to be modeled by a "tree of life" (Stammbaumtheorie); as a result, one deals with the congruence between, on the one hand, the simple-to-complex Darwinian evolution of biological organisms and, on the other hand, the postulated historical progression of languages (or their features) through variation and sub-speciation (DeGraff 2001: 217-218). Leaving aside the discussion of an isolating proto-language at the evolutionary beginning of each language phylum, Sanskrit or Russian with their inflecting (fusional) morphology are most advanced since, as argued by Schleicher and echoed by Dahl, inflecting (fusional) morphology marks the highest degree of maturity (complexity) and perfection. If not more thoroughly theoretically-grounded, such an age-cum-complexity approach serves not only as the chief measure of evolutionary progress and complexity but also brings us back to the 17 th to 19th century, when the inflecting Indo-European languages were considered by default to be superior to non-inflecting languages. Additionally, the modern "organic" theory
} 
Distinguishing the aforementioned differences in the perspectives of the egoet-nunc communicative scope, on the one hand, in Slavic and, on the other hand, in Romance and Germanic allows us to explain possible changes in both the external and internal determinant.

\section{Complexification versus simplification}

Since the ego-et-nunc communicative scope has undergone historical changes in Indo-European, the question arises as to how one should treat the corresponding changes in the two groups of inflecting Indo-European, i.e. the analytic Romance and Germanic next to the synthetic Slavic. One should bear in mind that the internal determinant of Slavic is characterized by the prospection of the ego-et-nunc communicative scope, which results, according to Mel'nikov (1969: 67), in the economical use (fusion) of both relational and derivational meanings. At the same time Romance and Germanic demonstrate increasing analytic features due to the historical (retrospective) change in the perspective of the ego-et-nunc communicative scope. Hence the tendency to use grammatical meanings less economically, for instance, in periphrastic tense forms. ${ }^{6}$

One wonders at this point whether prospection and retrospection reflect "high maturity" and "low maturity" of linguistic features conceived of by Dahl as exponents of complexification and simplification respectively? Is it worth then pursuing the hypothesis that it is in low-contact speech communities that one is most likely to find not only the preservation of complexity but also an increase in complexity, i.e. irregularity, opacity, syntagmatic redundancy and the like (Trudgill 2011: 64)? Is it really so that simplification is actually not "normal"? Can we also agree that the "natural tendency" for languages, if "left alone", not in contact, is to accrue more and more complexity as a result of connatural changes, not to simplify (Trudgill 2011: 152)?

Before bringing the aforementioned questions in line with Mel'nikov's theory, one should look into some arguments advanced by Dahl (2004: 283-284) pondering similar conundrums. One should note right away that Dahl does not take into consideration the system of societal factors whose specific configurations (external

of "maturation" neglects abrupt or rapid changes in the history of Indo-European. Although with great reservations, the notion of maturation may be linked with the Indo-European material, perhaps primarily with Slavic which has elaborated on the fusional character of IndoEuropean inflection. Yet this association should be well grounded in the reconstruction of the internal and external determinants of individual Slavic and other Indo-European languages.

6 While discussing various "shifters" in natural languages, in particular time-reference, Dixon (1979: 98) noted that only in a few [Indo-European] languages time can be viewed by looking in both directions from the constant origin "now". Thus, he postulated equal grammatical status to "past", "present", and "future" in Ancient Greek. This view corroborates our theory about the historical split of the ego-et-nunc communicative scope in Indo-European into the two opposed perspectives (aspects) of one and the same type (scope) of communication in the two groups of the historical Indo-European dialects. 
determinants) could bring about specific language changes. He believes, for instance, that the growth of periphrastic constructions might be causally linked with "a general trend [of inflecting systems] from a synthetic to an analytic language type" (Dahl 2004: 282). Arguably, the notion of "general trend" in the case of periphrastic constructions is not corroborated by (East) Slavic data (Danylenko 2005a, 2005b). This is why, perhaps, Dahl sounds rather pessimistic in drawing his final conclusion. According to him, the large-scale changes that have taken place in Western European languages over the last two millennia, the result of which has been a significant reduction of morphological complexity, have contributed to a biased picture of what "typical" language change is like (Dahl 2004: 285).

Overall, the concepts of "typical" language and "general trend" appear deceptive. Quite in the same vein, the notions of natural (normal) change vs. non-natural change look misleading, if not placed in a wider typological context of the period of "maturation" of inflecting phenomena (cf. Dahl 2004: 111-115). In order to measure the level of complexity of a certain change, it is not enough to approach it in absolute or relative terms (Miestamo 2008: 24-29, 2009: 81-84). The absolute approach which measures complexity in objective terms as the matter of parts in a system, of connections between different parts and the like, does not account for language speakers whose use of language is subject to the influence of external (societal) factors, including but not limited to language contact. The metric for measuring complexity in objective terms, that is, in relation to language users is also seen as rather fuzzy. Complexity is thus identified with cost and difficulty of processing and learning, especially in contact situations. Moreover, as Miestamo (2009: 81) surmised, the notion of relative complexity is problematic in typological research and, one should add, also in genealogical and areal consideration.

According to Miestamo (2009: 83, also 2008), functional domains supply a useful tertium comparationis for approaching the complexity of specific "subsets of grammar". For instance, as Miestamo (2009: 83) hypothesized, we may study and compare the complexity of tense systems across languages and say that according to the Principle of Fewer Distinctions, a language with two grammatical distinctions is less complex than one with five. Consequently, for instance, Russian with its three tenses should be treated as less complex in comparison with modern French characterized by eight tense paradigms. However, as has been mentioned, Slavic, and especially Russian, has developed such a complex system of aspects and procedurals that, from the point of view of a "typical" language learner, its system will be more difficult to acquire than the extensive system of tense paradigms attested in the analytic languages of Western Europe.

Whether a change constitutes simplification or complexification, one should reconstruct its genetic, typological, and areal progression from the systemic point of view. ${ }^{7}$ I suggest that, first, a change needs to be traced g e n e t i c a 11 y back to

Such an approach is conspicuously absent in contemporary approaches to linguistic complexity, including a classification of system complexity, structural complexity and output complexity in Dahl (2004: 42-43, 44, 48-49). Certain details aside, the aforementioned complexities can 
the point of its engenderment. For Indo-European, a change should be profiled through the prism of the ego-et-nunc communicative scope. Second, the "maturation" of a particular change should be gauged t y pologic ally in accordance with the language's internal determinant. For the historical Indo-European dialects, as mentioned, one distinguishes between two types of the underlying ego-et-nunc communicative scope instantiated by its prospection and retrospection perspectives (aspects). Finally, a change can lead to an a r e a 1 convergence that ideally admits both expression-oriented (replacive and additive) borrowings as in Copper Island Aleut (Comrie 2008) and content-oriented replication (Heine, Kuteva 2005:34-37). Cases of borrowing and replication may be treated as extreme results of convergence of the external determinants and, ultimately, of the internal determinant(s) of the languages in contact. This explains, for instance, the change of the prospective perspective of the event-oriented ego-et-nunc communicative scope to retrospection in Balkan Slavic.

In the remainder, I discuss four types of possible changes in the ego-et-nunc communicative scope, i.e. synthetic complexification (Section 3.1), analytic simplification (Section 3.2), synthetic simplification (Section 3.3), analytic complexification (Section 3.4).

\subsection{Synthetic complexification}

One can speak about complexification or simplification, if only remaining within the confines of one and the same internal determinant. If a change leads to a deeper adaptation (maturation) of the inflecting language system due to stable societal factors and lack of long-term contact, it can be viewed as complexity-development. Conversely, reflecting a d e viat ing $\mathrm{dr}$ if $\mathrm{t}$ of the inflecting language system, a change can be deemed as simplification process due to the strengthening of analyticity as observed in the languages of Western Europe. They all are characterized by the reduction of grammatical patterns such as conjugations, declensions, and inflected forms, the rise of articles, an increase in the use of adpositional and periphrastic constructions, the development of fixed word order, and the like (Dahl 2004: 281). A deviating drift of the inflecting language system can be brought about, according to Mel'nikov (2003: 107, 138-141), by changes in the societal factors, including the size and homogeneity of speech community, the degree of heredity of linguistic and cultural experience, and constraints on the communication intervals. Conceivably, only cardinal changes in the external determinant, not necessarily of cataclysmic type as postulated in the punctuated equilibrium model by Dixon, are likely to trigger a change in the internal determinant. ${ }^{8}$

be described in absolute, relative and functional terms which, I believe, do not reflect a particular interaction of a language system with the corresponding system of societal variables.

8 The same reasoning is likely to be applied to a non-inflecting system. Thus, tentatively, a transformation of the internal determinant because of "unusual" changes in the societal factors might have caused a drift of the languages of East Timor to a "bizarrely analytic typology" (McWhorter 2008: 179-181). 
An obvious instance of complexity-development or, to use Dahl's term, "maturation" is found in Slavic with an exception, perhaps, of Balkan Slavic (Bulgarian, Macedonian, and the southernmost and eastern dialects of Serbian, including the Prizren-Timok and Torlakian dialect groups, all belonging to the Balkan Sprachbund, see Hetzer 2010). For instance, East Slavic is well known to have developed a complex system of aspects and procedurals that are found nowhere else in the inflecting (Indo-European) languages. Complexity-developments of this type provoked by the strengthening of synthetic features can be viewed as instances of $\mathrm{s} y \mathrm{nt}$ h e $\mathrm{t}$ i $\mathrm{c}$ complexification.

\subsection{Analytic simplification}

The emergence of analytic features in Romance and Germanic should be treated as a case of simplification. The corresponding reanalysis of the internal determinant could have been brought about by changes in the societal factors, including a decrease of the homogeneity of speech communities as a corollary of long-term language contact. To give a telling example, such changes could have triggered a drift toward analyticity in Balkan Slavic. The latter is characterized, in particular, by a reduction in the system of morphological cases, the formation of a future tense based on a reduced, often invariant, form of the verb 'to want', the use of an enclitic (postposed) definite article and so forth (Joseph 2010: 621-623).

As discussed elsewhere (Danylenko 2015: 283-285), an extreme case of analytic simplification for the comitative-instrumental polysemy is a loss of the instrumental inflection (4) through the neutralization of the instrumental-comitative opposition in East Serbian (Sobolev 2009: 719):

(4)

\begin{tabular}{|c|c|c|c|}
\hline a. & $\begin{array}{l}\text { Režem } \\
\text { cut-prs.1sg. }\end{array}$ & $\begin{array}{l}\text { nožer } \\
\text { knife }\end{array}$ & $\begin{array}{l}n \\
\text {-instr. }\end{array}$ \\
\hline b. & $\begin{array}{l}\text { Režem } \\
\text { cut-prs.1sg. }\end{array}$ & $\begin{array}{l}s \\
\text { with }\end{array}$ & $\begin{array}{l}\text { nož-em } \\
\text { knife-instr. }\end{array}$ \\
\hline c. & $\begin{array}{l}\text { Režem } \\
\text { cut-prs.1sg. }\end{array}$ & $\begin{array}{l}s \\
\text { with }\end{array}$ & $\begin{array}{l}n o \check{z} \\
\text { knife- } \varnothing\end{array}$ \\
\hline
\end{tabular}

Similar changes in encoding, leading to a loss of phonetic substance in inflection, are observed in the eastern Aukštaitian (Lithuanian) dialect of Biržaj, characterized by a loss of short vowels, $a, e, i, u$ in Auslaut, in particular in the instrumental singular in connection with changes in pitch and stressing (Jašinskaitè 1957: 190; Nepokupnyj 1964: 68). A typologically similar phonetic reduction is attested in a Slovene dialect of the Littoral group spoken around the mid-stream of the river Soča (Logar 1958: 110). In both the Lithuanian and Slovene dialects, the instrumental case ending (among a number of other cases) was dropped for singular in the prepositional phrase with the comitative preposition $s u / s$ : 
(5) dial. (Biržaj) Li. (Fraenkel 1929: 187)

Su ãkmen'(< ãkmeniu-instr.)

with stone

'with a stone'

(6) dial. (Soča) Slv. (Logar 1958: 110)

yrâ $s$ krâv pu ciest

go-prs.3sg. with cow-nom.sg.f. along road-acc.sg.f.

'He goes with a cow along the road.'

I proposed to treat the above-mentioned loss of inflection in the Lithuanian dialect of Biržaj and the Slovene Soča dialect as part of analytic simplification due to the strengthening of secondary analytic features in the inflecting language system (Danylenko 2015: 269, 283-285). Incidentally, the case of the Soča dialect is quite revealing in another sense. The point is that no such loss is observable in the "highcontact" Slovene dialect of Resia (rezijansko), spoken for centuries in northeastern Italy (see Steenwijk 1992: 171).

An interesting case of analytic simplification, identified in 1875 by Baudouin de Courtenay (Boduèn-de-Kurtenè 1875: 89-101) as "vowel harmony", is found in nonaccented vocalism of the aforementioned Slovene dialect of Resia (rezijansko); note that this type of vowel harmony is based on (1) the opposition of non-centralized vs. centralized vowels and (2) the opposition of high vs. non-high vowels, cf. otrokà (gen.) and utrûk (gen.), otroké (acc.) 'son' (Steenwijk 1992: 12-13). Baffled by this phenomenon in modern Slavic, Baudouin de Courtenay (Boduèn-de-Kurtenè 1875: 119-121) hypothesized that its appearance was a result of a very heavy "Turan" influence during contacts with the speakers of some Ural-Altaic agglutinative languages. By contrast, however, one should be reminded about some less-Turkicized Asia Minor Greek varieties. Although affected by a long-term contact with Turkish they showed an analy tic drift in the development of a vowel harmony which is different from that in the adjacent Turkish-speaking varieties. Neither replicated nor borrowed, this indigenous Greek type of vowel harmony has lead to a partial reanalysis (from fusion to agglutination) in the morphological structure of nouns in these less-Turkicized dialects (Revithiadou et al. 2006). ${ }^{9}$

\subsection{Synthetic simplification}

This section is concerned with sy $\mathrm{thet}$ ic simplificatio $\mathrm{n}$ which is driven by the weakening of the primary synthetic features in the inflecting languages.

This vowel harmony is different from the vowel harmony acquired by the heavily Turkicized Cappadocian dialects spoken in Asia Minor. In fact, as Janse (2009: 38) pointed out, one can speak in this case about a Greek-Turkish mixed language, typologically closer to Turkish than to Greek. While exhibiting full-fledged agglutinative morphology and SOP-type word order, the Cappadocian dialects constitute an extreme case of language contact leading to "typological disruption" and "nongenetic development" (Janse 2009: 50). 
The most obvious case is North Russian where the use of the instrumental case ending to mark both comitative and instrumental participants is quite common. At first glance, it is tempting to assume that the lack of the comitative preposition $s$ in North Russian might reflect the older syncretism lost in the history of all other (eastern) Slavic dialects. However, as Požarickaja (2004: 139) argued, the comitative constructions of the type (7) constitute a dialectal and colloquial innovation based on ellipsis of the information redundant from the point of view of the speaker; this is why such northern Russian examples do not purportedly convey the participant function "means" long ago lost in the history of Russian (Požarickaja 2004: 135).

(7) NR Priexala synom

come-pst.sg.f. son-instr.sg.m.

'She came with her son.'

As Mel'nikov (2003: 113-116) suggested, such simplification can be observed in an inflecting language drifting from nominativity (event-oriented ego-et-nunc communicative scope) back to its ergative stage shaped by the attribute-oriented communicative scope (Danylenko 200o/1997: 44-45). Based on Lutin (1990), I argued elsewhere (Danylenko 2000/1997, 2002, 2005a, 2005b) that non-agreeing possessive resultatives with indeclinable, erstwhile neuter singular forms in -no and -to in the predicate and the locative construction with the preposition $u$ to render the S NP are innovations in North Russian as well as some Ukrainian dialects; the patient-salient argument in such constructions can be marked by the nominative (8b) or accusative (8c) case:

(8) NR a. u nego byto

at he-gen. be-indecl.[n.sg.ppp.]

'He has been (everywhere).'

b. u nego lavka pomyto

at he-gen. bench-nom.sg.f. wash-indecl.[ppp.n.sg.]

c. u nego lavku pomyto

at he-gen. bench-acc.sg.f. wash-indecl.[ppp.n.sg.]

'(By him) the bench has been washed.'

Deserving of attention is another invariable form in $-n$ and $-t$, first attested in the 19th century, where the zero desinence is used as a competing means of impersonalizing the passive (agreeing) construction (Danylenko 2006: 242):

(9) NR korova napojen

cow-nom.f.sg. give.to:drink-indecl.[ppp.m.sg.]

'The cow has been given to drink.'

No doubt, such morphosyntactic patterns could have arisen as a result of cardinal changes in the external determinants of the corresponding speech communities. Speakers (who probably scarcely numbered dozen or so) of some of the northern Russian dialects were mostly refugees from central regions of Russia who began to 
settle down in seclusion in the dense forests of the North, beginning in the early 19th century (Lutin 1990).

The development of the aforementioned Russian dialectal constructions, referred to by Mel'nikov (2003: 125) and independently from him by Orr (1989: 17) as "embryonically ergative", does signal a drift from nominativity to ergative-type patterning. The latter may well be realized in small speech communities with a high degree of the heredity of linguistic and cultural experience due to a lack of short- and long-term contacts with immediate neighbours. Unlike a solid ergative system, the ergative patterning in North Russian selectively covers particular (resultative) communicative situations (Lutin 1990: 16; Mel'nikov 2003: 118, 125); the latter hypothesis corresponds well with a universal type-independent pressure toward ergative clause alignment in the spontaneous spoken discourse of all speech communities using inflecting languages (Du Bois 1987: 850).

\subsection{Analytic complexification}

In contrast to predicate-verb which developed in Indo-European with the ego-etnunc communicative scope (see Mel'nikov 1988: 24-25), the indeclinable proto-verbal form in -no and -to, as illustrated in (8a-c) can be conceived of as predicate-attribute (Danylenko 2000/1997: 44-45, 2005a: 369); this type of predicate is functionally compatible with the concept of the diathetically non-oriented predicates as found in polysynthetic languages, for instance, in Polynesian Tongan (Tchekhoff 1978: 43-46).

Spoken in small homogeneous and closely-knit communities, polysynthetic languages demonstrate a different communicative scope, zooming in, according to Mel'nikov (2003: 124-125), on the "state of affairs" obtaining between the members of such a community. Stems used in such languages are not distinguished at all for lexical category (Mithun 1999: 56-57). A possible change in the current state of affairs results in assigning some new quality to a situational modifier that tends to be gradually differentiated with respect to its new semantic role(s). Hence the appearance of agent- and patient-salient participants (Danylenko 200o/1997: 46-47) as reflected in the agent/patient, ergative/absolutive or other categories and their combinations in some North American polysynthetic languages (Mithun 1999: 204-221). For instance, in example (10a), the Inuktitut incorporating -tuq 'to eat' occurs in a construction without the ergative marker; yet in (1ob), the independent niri- with the same meaning is attested in a non-incorporating construction in combination with the ergative alignment (Allen 1996: 158):

(10) Ink. a. Jaani iqaluturluq (<iqaluq-tuq-juq)

Jaani-abs. fish.eat-3sg.

b. Jaani-up iqaluk niri-janga

Jaani-erg. fish-abs. eat-3sg.

'Johnny is eating/ate (the) fish.' 
Dahl (2004: 220-221) questions the status of these and similar patterns - whether they should be regarded as incorporation or not. The appearance of the ergative alignment within the incorporating system signals a further progression of the agent-patient differentiation accompanied by a new syntactic orientation. Under changing societal variables of the speech community, all this can ultimately lead via the active-type alignment to the emergence of ergative grammar (see Klimov 1979).

The ergative-like equivalent reserved for the agent-salient participant is found, as we have noted, in the PP $u+$ genitive case attested in North Russian and some Ukrainian dialects (Section 3.3). Other means of encoding the agent-salient participant, attested both in Slavic and Baltic (Danylenko 2005b), can be projected on an agentive continuum; assigned the highest rank in the hierarchy of agenthood as reconstructed for the inflecting languages, the instrumental case in (1) and (2) is a relatively new means among all other agentive phrases still used in Slavic (Danylenko 2005a: 360-362, 2006: 231-233).

Thus, the emergence of the direct object as a complementation of the indeclinable proto-verbal form (predicate-attribute) in -no and -to accompanied by the agent-salient participant encoded through the PP $u+$ genitive case is a tentative case of analytic complexification. The latter change is strengthened in the nominative-accusative clause alignment through the introduction of a periphrastic passive construction with the agent-salient participant rendered by a PP as in Polish, see (3).

\section{Conclusion}

The foregoing discussion of Mel'nikov's theory offers several theoretical implications.

Unlike Trudgill's emphasis on complexification and simplification as two principal linguistic changes, the Indo-European languages, as argued by Mel'nikov and his followers, demonstrate far more variegated changes in their internal determinants (see Table 1). The projection of complexification and simplification on the gradient scale of primary syntheticity and the gradient scale of secondary analyticity in the inflecting Indo-European languages produces in total four possible types of changes in their internal determinant; they are presented, together with the respective societal variables (external determinants), in Table 1.

Note that these changes are not immediately dependent on language contact or isolation. Contact and isolation can be treated only as f a çade sig n a t u r e s of particular configurations of such societal factors as the size of speech community, the degree of its homogeneity, constraints on communication intervals, and the degree of heredity in transmitting linguistic and cultural experience from one generation to another.

In dealing with simplification and complexification as sociolinguistic categories, one should take into consideration not only diachronic aspect as reiterated recently by Haspelmath and Michaelis (2017: 5; see Schwegler 1990: 49) but the 


\begin{tabular}{|c|c|c|c|c|}
\hline $\begin{array}{l}\text { Develop- } \\
\text { mental } \\
\text { process }\end{array}$ & $\begin{array}{c}\text { Primary } \\
\text { syntheticity }\end{array}$ & $\begin{array}{c}\text { Societal } \\
\text { variables }\end{array}$ & $\begin{array}{l}\text { Secondary } \\
\text { analyticity }\end{array}$ & $\begin{array}{c}\text { Societal } \\
\text { variables }\end{array}$ \\
\hline 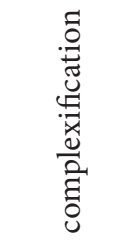 & $\begin{array}{l}\text { synthetic } \\
\text { complexifi- } \\
\text { cation }\end{array}$ & $\begin{array}{l}\text { isolation } \\
\text { homogeneous } \\
\text { mega-community } \\
\text { communication } \\
\text { constraints } \\
\text { high heredity }\end{array}$ & $\begin{array}{l}\text { analytic } \\
\text { complexifi- } \\
\text { cation }\end{array}$ & $\begin{array}{l}\text { isolation/contact } \\
\text { homogeneous } \\
\text { mega-community } \\
\text { no communication } \\
\text { constraints } \\
\text { high heredity }\end{array}$ \\
\hline 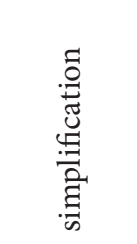 & $\begin{array}{l}\text { synthetic } \\
\text { simplifica- } \\
\text { tion }\end{array}$ & $\begin{array}{l}\text { isolation } \\
\text { homogeneous } \\
\text { micro-community } \\
\text { no communication } \\
\text { constraints } \\
\text { high heredity }\end{array}$ & $\begin{array}{l}\text { analytic } \\
\text { simplifica- } \\
\text { tion }\end{array}$ & $\begin{array}{l}\text { contact } \\
\text { heterogeneous } \\
\text { macro-community } \\
\text { communication } \\
\text { constraints } \\
\text { high heredity }\end{array}$ \\
\hline
\end{tabular}

Table 1 . The typology of changes in relation to societal variables

genetic, typological, and areal dimensions of the respective changes in the internal determinant. In other words, complexity metric rests on primarily the genetic and typological aspects of changes taking place in languages with similar internal determinants. However, areal convergences in the neighbouring languages with different determinants become possible due to historical adjustments in their external determinants identified primarily with language contact as is the case with the Slovene dialects spoken in the Friuli-Venezia Giulia region or Balkan Slavic. The resulting structural similarities and the degree of their simplification or complexification can be measured therefore against the newly adapted internal determinant.

What is clear thus far is that, despite recent progress in the discussion of complexity-development in connection with different factors, including language contact, the quest for possible explanations of language change or, more globally, the correlation of linguistic patterning and societal structures, is far yet over. To achieve a new explanatory potential, the social determinants as advanced in the sociolinguistic typology of Trudgill need to be supplemented with an insight into the internal determinants of different types and their possible changes as discussed in the systemic typology of Mel'nikov. Such a synthesis will shed new light on the nature of the correlation of language and society as well as prepare a new ground for future research on such ubiquitous terms as contact, borrowing, and replication that are commonly treated today in the grammaticalization theory, areal typology, historical linguistics and other related disciplines (see Boček 2014: 107-200). 


\section{Abbreviations}

$\mathrm{ABS}=$ absolutive; $\mathrm{ACC}=$ accusative; $\mathrm{AUX}=$ auxiliary; dial. $=$ dialectal; $\mathrm{ERG}$ = ergative; ESrb. = East Serbian; $\mathrm{F}=$ feminine; INDECL $=$ indeclinable; Ink. = Inuktitut; INSTR $=$ in strumental; Li. $=$ Lithuanian; $\mathrm{M}=$ masculine; $\mathrm{N}=$ neuter $\mathrm{NOM}=$ nominative; $\mathrm{NR}=$ North Russian; $\mathrm{P}$ = Polish; $\mathrm{PL}$ = plural; $\mathrm{PPP}=$ past passive participle; $\mathrm{PRS}=$ present tense; $\mathrm{PST}=$ past tense; $\mathrm{R}=$ Russian; $\mathrm{REFL}=$ reflective; $\mathrm{SG}=$ singular; Slv. = Slovene

\section{References}

Allen Sh.E.M. 1996. Aspects of argument structure acquisition in Inukitut. Philadelphia.

Boček V. 2014. Praslovanština a jazykový kontakt. Prague.

Boduèn-dè-Kurtenè I. [= Baudouin de Courtenay J.N.I.]. 1875. Opyt fonetiki rez'janskix govorov. Warsaw, St. Petersburg.

Capell A. 1965. A typology of concept domination. - Lingua 15.5: 451-462.

Comrie B. 2008. Inflectional morphology and language contact, with special reference to mixed languages. - Simund P., Kintana N. (eds.). Language contact and contact languages. Amsterdam: 15-32.

Dahl Ö. 2004. The growth and maintenance of linguistic complexity. Amsterdam, Philadelphia.

Danylenko A. 2000/1997. The genitive of agent and the instrumental of means in Old Ukrainian: An old idea worth revising? - General Linguistics 37.1: 41-70.

Danylenko A. 2002. The East Slavic 'HAVE': Revising a developmental scenario. - JonesBley K. et al. (eds.). Proceedings of the 13th Annual UCLA Indo-European Conference; Los Angeles, November 9-10, 2001. Washington: 105-127.

Danylenko A. 2003. Predykaty, vidminky i diatezy v ukrajins'kij movi: istoryčnyj i typolohičnyj aspekty. Kharkiv.

Danylenko A. 2005a. Is there any possessive perfect in North Russian? - Word 56.3: 347-379.

Danylenko A. 2005b. Impersonal constructions with the accusative case in Lithuanian and Slavic (A reply to Axel Holvoet). - Zeitschrift für Slawistik 50.2: 147-160.

Danylenko A. 2006. Slavica et islamica: Ukrainian in context. München.

Danylenko A. 2011. Is there any inflectional future in East Slavic? A case of Ukrainian against Romance reopened. - Nomachi M. (ed.). Grammaticalization in Slavic languages. Sapporo: $147-177$.

Danylenko A. 2012. Auxiliary clitics in Southwest Ukrainian: Questions of chronology, areal distribution, and grammaticalization. - Journal of Slavic Linguistics 20.1: 3-34.

Danylenko A. 2013. Ukrainian in the language map of Central Europe: Questions of arealtypological profiling. - Journal of Language Contact 6.1: 134-159.

Danylenko A. 2015. On the mechanisms of the grammaticalization of comitative and instrumental categories in Slavic. - Journal of Historical Linguistics 5.2: 267-296.

Danylenko A. 2016. Oleksandr Popov (1855-80) and the reconstruction of Indo-European noun inflection. - Language and History 59.2: 112-130.

Danylenko A. 2018. The correlation of linguistic patterning and societal structures in systemic typology. - Studia Linguistica Universitatis Iagellonicae Cracoviensis 135: 81-96.

DeGraff M. 2001. On the origin of creoles: A Cartesian critique of Neo-Darwinian linguistics. - Linguistic Typology 5.2/3: 213-310.

Dixon R.M.W. 1979. Ergativity. - Language 55.1: 59-138.

Drinka B. 2017. Language contact in Europe. The periphrastic perfect through history. Cambridge. 
Du Bois J.W. 1987. The discourse basis of ergativity. - Language 63.4: 805-855.

Fleischman S. 1983. From pragmatics to grammar. - Lingua 60.2/3: 183-214.

Fraenkel E. 1929. Syntax der litauischen Postpositionen und Präpositionen. Heidelberg.

Haspelmath M., Michaelis S.M. 2017. Analytic and synthetic: Typological change in varieties of European languages. - Buchstaller I., Siebenhaar B. (eds.). Language variation - European perspectives VI. [Selected papers from the 8th International Conference on Language Variation in Europe, Leipzig 2015]. Amsterdam: 1-17.

Heine B., Kuteva T. 2005. Language contact and grammatical change. Cambridge.

Hetzer A. 2010. Das südosteuopäische Areal. - Hinrichs U. (ed.). Handbuch der Eurolinguistik. Wiesbaden: 457-473.

Janse M. 2009. Greek-Turkish language contact in Asia Minor. - Études helléniques / Hellenic Studies 17: 37-54.

Jašinskaitė I. 1957. Kirtis, priegaidè ir jų poveikis vokalizmui Biržų tarmèje. - Lietuvių kalbotyros klausimai 1: 189-195.

Joseph B.D. 2010. Language contact in the Balkans. - Hickey R. (ed.). The handbook of language contact. Malden (MA): 618-633.

Klimov G. 1979. On the position of the ergative type in typological classification. - Plank F. (ed.). Ergativity. Toward a theory of grammatical relations. London: 327-332.

Kulikov L. 2009. Evolution of case systems. - Malchukov A., Spencer A. (eds.). Case. Oxford: 439-457.

Logar T. 1958. O izgubi nominalnih končnic v nekaterih slovenskih primorskih govorih. Slavistična revija 1.11: 109-112.

Lutin S.A. 1990. Sistemno-tipologičeskij analiz rezul'tativnyx konstrukcij russkix govorov Severa i Severo-Zapada. [Candidate of Science Dissertation; Peoples' Friendship University, Moscow].

McWhorter J.H. 2008. Why does a language undress? - Miestamo M., Sinnemäki K., Karlsson F. (eds.). Language complexity. Typology, contact, change. Amsterdam, Philadelphia: 167-190.

Mel'nikov G.P. 1969. Jazykovaja stratifikacija i klassifikacija jazykov. - Edinicy raznyx urovnej jazyka i ix vzaimodejstvie. Moscow: 45-73.

Mel'nikov G.P. 1971. Determinanta - veduščaja grammatičeskaja tendencija jazyka. - Fonetika, fonologija, grammatika. [K semidesjatiletiju A.A. Reformatskogo]. Moscow: 359-367.

Mel'nikov G.P. 1973. Sistemnyj podxod v lingvistike. - Sistemnye issledovanija 1972. Moscow: $183-204$.

Mel'nikov G.P. 1980. Priroda padežnyx značenij i klassifikacija padežej. - Issledovanija $v$ oblasti grammatiki i tipologii jazykov. - Moscow: 39-64.

Mel'nikov G.P. 1986. Sistemnaja lingvistika Gumbol'dta-Sreznevskogo-Potebni-Boduèna i sovremennaja sistemnaja tipologija jazykov. - Problemy tipologičeskoj, funkcional'noj i opisatel'noj lingvistiki. Moscow: 13-26.

Mel'nikov G.P. 1988. Kommunikativnyj rakurs - osnova semantičeskogo i grammatičeskogo svoeobrazija jazyka kak izobrazitel'noj znakovoj sistemy. - Metodologija lingvistiki i aspekty izučenija jazyka. Moscow: 13-26.

Mel'nikov G.P. 2003. Sistemnaja tipologija jazykov. Moscow.

Miestamo M. 2008. Grammatical complexity in a cross-linguistic perspective. - Miestamo M., Sinnemäki K., Karlsson F. (eds.). Language complexity. Typology, contact, change. Amsterdam, Philadelphia: 23-41.

Miestamo M. 2009. Implicational hierarchism and grammatical complexity. - Sampson G., Gil D., Trudgill P. (eds.). Language complexity as an evolving variable. Oxford: 80-97. 
Mithun M. 1999. The languages of native North America. Cambridge.

Nepokupnyj A.P. 1964. Areal'nye aspekty balto-slavjanskix otnošenij. Kyiv.

Orr R.A. 1989. Russo-Goidelic syntactic parallel: u nego svoja izba postavlena / tá sé déanta agam. - General Linguistics 29.1: 1-21.

Orr R.A. 1999. Evolutionary biology and historical linguistics. - Diachronica 16.1: 123-157.

Popov A.V. 1881. Sintaksičeskija izslědovanija. I. Imenitel'nyj, zvatel'nyj i vinitel'nyj vo svjazi sъ istorijej razvitija založnyxъ značenij i bezličnyxъ oborotovъ vъ sanskritě, zendě, grečeskomz, latinskomz, německomz, litovskomz, latyšskomz, i slavjanskomъ narěčijaxъ. Voronež.

Potebnja A.A. 1941. Iz zapisok po russkoj grammatike. [vol. 4: Glagol. Mestoimenie. Čislitel'noe. Predlog]. Moscow, Leningrad.

Požarickaja S.K. 2004. Bespredložnyj tvoritel'nyj padež v severnorusskix govorax na obščeslavjanskom fone (semantika i sintaksis). - Issledovanija po slavjanskoj dialektologii 9: Metody izučenija territorial'nyx i social'nyx dialektov. K itogam opyta slavjanskoj dialektologii XX v. Moscow: 131-158.

Revithiadu A., Ostendorp M. von, Kalomoira N., Tiliopoulou M.-A. 2006. Vowel harmony in contact-induced systems: The case of Asia Minor dialects of Greek. - Janse M., Joseph B., Rally A. (eds.). Proceedings of the 2nd International Conference on Modern Greek Dialects and Linguistic Theory. Patras: 350-365.

Sakhno S. 2011. Pourquoi deux génitifs et deux locatifs en russe pour certains substantifs? État actuel des paradigmes et aspects diachroniques. - Fruyt M., Mazoyer M., Pardee D. (eds.). Grammatical case in the languages of the Middle East and Europe. Chicago: 359-371.

Schleicher A. 1873 [1863]. Die Darwinische Theorie und die Sprachwissenschaft. Weimar.

Schwegler A. 1990. Analyticity and syntheticity. A diachronic retrospective with special reference to Romance languages. Berlin, New York.

Shevelov G.Y. 1965. A prehistory of Slavic. New York.

Sobolev A.N. 2009. From synthetic to analytic case. Variation in South Slavic dialects. Malchukov A., Spencer A. (eds.). Case. Oxford: 716-729.

Steenwijk H. 1992. The Slovene dialect of Resia San Giorgio. Amsterdam, Atlanta.

Tchekhoff C. 1978. Aux fondements de la syntaxe: l'ergatif. Paris.

Trudgill P. 1996. Dialect typology: Isolation, social network and phonological structure. Guy G.R., Feagin C., Schiffrin D., Baugh J. (eds.). Towards a social science of language. [vol. 1: Variation and change in language and society]. Amsterdam, Philadelphia: 3-21.

Trudgill P. 1997. Typology and sociolinguistics: Linguistic structure, social structure and explanatory comparative dialectology. - Folia Linguistica 31.3/4: 349-360.

Trudgill P. 2010. Contact and sociolinguistic typology. - Hickey R. (ed.). The handbook of language contact. Malden (MA): 299-319.

Trudgill P. 2011. Sociolinguistic typology. Oxford. 
